\title{
Exploring network governance in urban regeneration, community involvement and integration
}

\author{
Gerard van Bortel · David Mullins · Mary Lee Rhodes
}

Received: 4 September 2008/Accepted: 14 December 2008/Published online: 18 March 2009

(C) The Author(s) 2009. This article is published with open access at Springerlink.com

\section{The agenda}

This special issue of Journal of Housing and the Built Environment on network governance in urban regeneration, community involvement and integration has emerged from a working group of the European Network of Housing Research (ENHR) on institutional and organizational dynamics in social housing. It builds on earlier work published in a special issue of Housing, Theory and Society on network perspectives in social housing (Mullins and Rhodes 2007) which provided a typology of approaches that can be applied to inter-organizational relationships (including policy and governance networks, supply chains and complex systems) in the housing studies field and some examples thereof and set an agenda for future analysis of network governance in housing studies. These examples illustrated through case studies some of the distinctive contributions of the network approach. These included the importance of the changing actors and characteristics of organizations participating in decision-making, sensitivity to context, recognition that context may be created by the participants themselves through their interactions, and the identification of minority and/or unsuccessful agenda-setting attempts which contribute to unanticipated outcomes and shifting goals. This opened up a potentially fruitful area for researchers to explore how housing systems change over time.

This special issue takes things a step further by bringing together research on network governance in the overlapping fields of urban regeneration, community involvement and integration in England, Sweden and the Netherlands. We have also engaged with the "second generation of research on governance networks" (Sørensen and Torfing 2007,

G. van Bortel ( ()

OTB Research Institute for Housing, Urban and Mobility Studies, Delft University of Technology,

Delft, The Netherlands

e-mail: g.a.vanbortel@tudelft.nl

D. Mullins

Centre for Urban and Regional Studies, University of Birmingham, Birmingham, UK

e-mail: d.w.mullins@bham.ac.uk

M. L. Rhodes

School of Business, Trinity College Dublin, Dublin, Ireland

e-mail: rhodesml@tcd.i.e 
p. 1). Influenced by work centred on the Centre for Democratic Network Governance at Roskilde University in Denmark in 2003 (Bogason and Zølner 2007; Sørensen and Torfing 2007; Markussen and Torfing 2007), this stream of work has involved more critical and nuanced perspectives on the efficacy of different types of network governance in different contexts, challenging the extent to which these networks really have a positive impact on 'wicked problems' and considering unanticipated impacts. In particular we address the issues raised by Sørensen and Torfing (2007) and Klijn and Skelcher (2007) concerning the relationship between networks and democracy, and we also address the concept of 'democratic anchorage', a key topic for second-generation network theorists.

All of the papers in this special issue consider the role of housing actors, but as our focus on networks would predict, the interest is in the interaction between housing organizations and other actors whose engagement is required to address societal problems. The complex fields we have selected exemplify the need to co-ordinate the decisions and actions of a pluriform set of actors including housing providers and policy-makers together with many other actors and thus provide a good testbed for network ideas.

The renewal of deprived neighbourhoods and low-quality housing stock is an important challenge in social housing throughout Europe. Network governance is gaining prominence as a mode of decision-making to harness the involvement of relevant actors in these processes. Patterns of new migration to countries like Sweden, UK and the Netherlands have been geographically focused, often on the same deprived neighbourhoods where such transformations are being attempted. Advocates of network governance highlight the necessity of networked forms of decision-making to manage uncertainty, resolve problems, access expertise and enable citizen engagement in a complex society with dispersed power and resources (Koppenjan and Klijn 2004, chap. 10).

There is now a need for analysis to evaluate and test the claims made about the benefits and efficacy of network governance in securing community involvement and assisting social integration in complex urban regeneration programmes and to explore the conditions necessary for these approaches to succeed (Van Bortel et al. 2007). This also introduces the need to reconsider the types of evaluation that are appropriate to programmes that are negotiated between network actors and in which goals are emergent rather than set hierarchically at the outset (Kickert et al. 1997a).

Network approaches of the type presented in this special issue occupy the space between micro and macro level analyses. This 'meso' approach to policy analysis (Hudson and Lowe 2004) incorporates the explicit recognition of interdependencies and interactions among various actors within policy arenas, the influence on processes and outcomes of the structure of power and relationships among actors, and the institutional context within which policy and actors must operate. Another important feature of network approaches is the attention paid to learning and adaptation by actors (Koppenjan and Klijn 2004).

In the next section we introduce the articles that we have included in this collection, show how they relate to theory and identify some key findings, particularly in illuminating some of the ambiguities associated with network governance. This leads us into a concluding discussion in which we summarize some of the emerging issues and identify five key implications for future research in this field.

\section{The papers}

This special issue contains three articles applying network analysis to urban renewal in the Netherlands. Buitelaar and De Kam focus on the capability of the Arnhem local authorities 
to achieve their goals in project development and housing production. Van Bortel explores the way housing associations and local authorities in Groningen try to deal with the complexity of decision-making on urban regeneration policy. Haffner and Elsinga focus on decision-making in different neighbourhoods in Amsterdam. Two further articles apply network analysis to the social integration of new migrants in Sweden and in England, again highlighting links with housing and regeneration decision-making. Hertting explores prospects of political integration of minority ethnic organizations in neighbourhood network governance in Sweden, while Mullins and Jones focus on refugee integration and access to housing in five different local housing markets in England. In a concluding review article, Van Bortel and Mullins bring together material from the five earlier articles to explore relationships between network governance and democracy.

\subsection{Theoretical perspectives}

As well as highlighting different policy contexts and national perspectives the papers also draw on different but related theoretical strands within the general field of networks. The following Table 1 summarizes the main frameworks used by the authors.

The most common framework adopted in these articles is the network management framework presented by Kickert et al. (1997b) and developed by Koppenjan and Klijn (2004). This is used with different emphases by Haffner and Elsinga, Mullins and Jones and Van Bortel. Meanwhile greater use is made of Sørensen and Torfing's (2007) concepts of network governance and the relationship with democracy by Hertting and by Van Bortel and Mullins.

Both of these frameworks are based on the assumption of interdependent actors whereby interactions are of a horizontal nature without a dominant party that can coerce the development of decision-making. Similar questions arising from steering without hierarchy are explored by Buitelaar and De Kam who draw on new institutional economics (Williamson 1996) and collaborative planning (Healey 1997) to explore the steering capacity of the local government and capability to achieve their goals in a more complex decision-making environment.

To unravel complexity in urban renewal decision-making Van Bortel and Haffner and Elsinga use De Bruijn and Ten Heuvelhof $(1999,2002)$ to explore some key features of networks such as closedness, pluriformity, interdependencies and dynamics. Interdependencies mean that actors need to interact; the sheer number and the changing decisionmaking landscape increase the pluriformity and dynamics. The different perceptions, goals and frames of reference highlight the closedness of actors making decisions in networks more complex. Connected to this is Koppenjan and Klijn's (2004) concept of uncertainties in networks used by Van Bortel. Complexity leads to substantive, strategic and institutional uncertainties that actors have to solve by interacting with each other.

Hertting's focus on democratic participation through migrant-led organizations is informed by the wider political science literature on democratic inclusion (Crowley 2001) as well as Sørensen and Torfing's (2007) concepts of network governance. Meanwhile Mullins and Jones approach a similar set of questions about the ability of refugee-led organizations to influence decisions affecting housing provision for refugees using the tools available within network management (Klijn and Teisman 1997).

\subsection{Recognizing the ambiguities}

A key feature of second-generation network governance research is the recognition of ambiguity. 


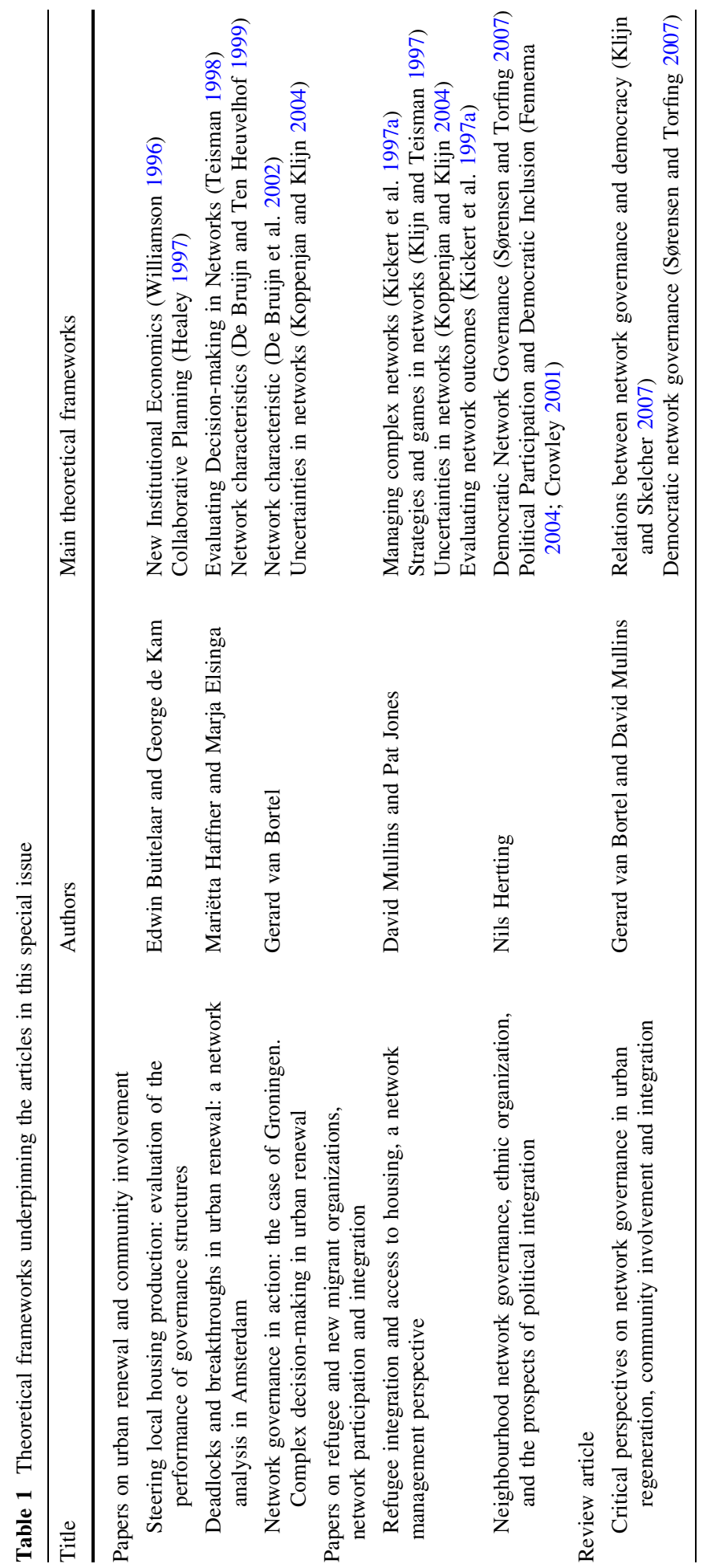


- First there is the view that in many cases the appearance of interdependent networks masks a reality of continued state dominance and steering.

- A second issue-related to the first—is that inequalities of power within networks can lead to quite hierarchical relationships focused on one or more dominant actors.

- Third, there is an ambiguous and often problematic relationship between network governance and representative democracy.

- The fourth and last issue is that the appropriateness and acceptability of network governance depends on the institutional and political context in which the decisionmaking takes place. (See Davies 2002; Bull and Jones 2006; Entwistle et al. 2007; Jones and Evans 2006; Swyngedouw 2005 for critical perspectives on network governance).

The papers in this special issue also address these ambiguities. Articles by Van Bortel and Haffner and Elsinga address the first ambiguity by taking an in-depth look at the role and outcomes of decision-making in urban renewal involving government actors, nonprofit housing providers and residents.

In relation to the second ambiguity, Buitelaar and De Kam found that local authorities in Arnhem often use indirect steering by withholding approval or postponing decisions on land-use plans. This approach of 'steering in the shadow of hierarchy' (Scharpf 1997) was also identified in a national study of the role played by the Dutch Ministry of Housing (Koffijberg 2005). Haffner and Elsinga present a similar result in the Amsterdam case study where the "Local government turned out to have the strongest role, as it was able to put to use their hierarchal powers by not giving the necessary permissions".

Mullins and Jones and Hertting connect with the third ambiguity issue of power inequalities in networks, more specifically the position of new migrant organizations. Both articles describe forms of 'institutional renewal', emphasizing not only the importance of 'horizontal' partnerships among local authorities and housing actors, but also 'bottom-up' participation and inclusion. Mullins and Jones illustrate the difficulties in balancing the power of very unequal actors with different immediate interests and priorities. In a case study covering newly established refugee community organizations as well as multi-million housing associations, they demonstrate the importance of constructing 'win-win' outcomes to balance interests rather than power.

Hertting illustrates some of the internal dynamics of minority ethnic associations. Although these governance networks claim to promote democratic and more inclusive decision-making, Hertting does not take this claim for granted. He concludes that under certain circumstances, participation of ethnic associations in governance networks may work as a mechanism of political integration. However, when he scrutinizes the different ways in which they may do so and how the surrounding institutional context may affect them, he finds somewhat contradictory answers. It seems that more centralized internal structures will restrict membership democracy and eventually the production of crucial resources in terms of consent and anchorage as well group information and knowledge.

The review article by Van Bortel and Mullins explores the democratic anchorage of decision-making in networks and rounds off the special issue by pulling together the contributions of the other papers on the relationship between networks and democracy.

The importance of context is highlighted by several contributions, including that by Mullins and Jones. They set out the national contextual factors that had led to a 'lack of political will' to tackle refugee housing needs and showed the importance of local context in comparing the operation of five local partnerships. 


\subsection{Network management and evaluation}

The third feature of network governance research highlighted by this collection of articles is their consideration of how networks are managed, the process criteria that can be applied and issues concerning the evaluation of network goals and outcomes.

Both Van Bortel and Mullins and Jones describe implicit examples of network management defined by Kickert and Koppenjan (1997) as "promoting mutual adjustment behaviour of actors with diverse objectives and ambitions with regard to tackling problems within a given framework of interorganisational relationships". In both articles active network managers could be distinguished.

Van Bortel's study of regeneration networks in Groningen describes the initiative by senior officials - CEOs of housing associations and a high-level local authority official- to try to solve a deadlock in decision-making concerning a new urban regeneration charter. In this case mutual interaction was stimulated by organizing a 'pressure-cooker' 2-day conference in a secluded location bringing together all relevant issues and actors from different hierarchical levels of the involved housing associations and municipal departments. In this way, the closedness and the pluriformity of the multitude of actors involved in urban regeneration decision-making was overcome.

Mullins and Jones explore what happens when an 'honest broker', with the legitimacy and connections required to manage relations between refugee community organizations and housing providers, uses network management approaches to do so. They explored the role played by the Housing Associations Charitable Trust (Hact) as the central network actor in a project it had set up to encourage local partnerships of refugee community organizations, housing providers and other agents to interact to achieve joint outcomes. While Hact did not use the language of networks, it did use non-hierarchical forms of steering to regulate the partnerships and share learning experiences. Mullins and Jones also discussed process criteria and found that different actors valued different elements in the decision-making process. Some valued the cognitive aspect (support to project members, training, and distribution of information) whereas others valued the institutional aspects (the evaluation framework) and still others valued the enrichment of decision-making by recycling emerging learning results into the project.

Accepting that mutual dependence of the actors is one of the most important characteristics of decision-making in networks, Haffner and Elsinga contend that these interdependencies mean that actors like housing associations and local authorities cannot ignore neighbourhood problems and that they cannot solve these problems without collaboration. This means that time is an important element in network governance: "If actors cannot reach agreement at a particular time, it will make sense for them to wait for a more favorable climate, remain vigilant to what is going on around them and be ready to avail themselves of fresh opportunities when they arise".

Another key feature of network management is that goals cannot be set 'at the outset and from above' but must emerge from negotiations between the actors. Buitelaar and De Kam state that it is problematic to focus on the realization of goals formulated by the local authorities prior to the start of decision-making interactions. Goals shift due to interactions with residents and other stakeholders. Although the local authorities could use powers of expropriation, they were very reluctant to do so because it could damage their relation with private landlords and property owners.

Haffner and Elsinga agree that in a network there cannot be an a priori definition of good performance. Following Teisman (1998) and Koppenjan and Klijn (2004) they argue that performance assessment has to be the outcome of negotiations in the network. This 
connects with the argument brought forward by Buitelaar and De Kam that "the less hierarchical the governance structure, the less the outcome can be evaluated against a set of detailed pre-determined goals" because the definition of goals is a dynamic element of the planning process as a whole. The same conclusion is drawn by Mullins and Jones in their article exploring the role of institutional networks in mediating integration of minority ethnic organizations: "we agree with Klijn and Teisman (1997, p. 114) that using joint interest as an evaluation criterion for policy making will drastically change the evaluation outcome". Mullins and Jones found that the most significant outcomes of the Accommodate programme were in fact based on emergent goals rather than a priori goals. This finding has clear implications for evaluation methodologies.

Consequently the findings in these articles support the governance networks assumption that outcome assessments should be based on a philosophy of evaluation based on capturing and promoting learning rather than checking compliance with ex-ante formulated goals. The theoretical frameworks used by Haffner \& Elsinga and Mullins \& Jones (Teisman 1998; Klijn and Teisman 1997, respectively) focus on satisficing, multi-goal achievement and decision enrichment by actors. Mullins and Jones wondered whether satisficing was more about ensuring that there was something in it for everyone (win-win) rather than getting everyone to sign up to the same joint goals.

\section{Where next?}

The articles in this special issue demonstrate both the potentials and dilemmas of network governance analysis. From this work we would identify the following challenges for nextgeneration network governance looking beyond the managerial approach to networks. The articles in this special issue suggest some interesting questions for further research in the field of housing and urban studies.

- We need to increase our understanding of democratic anchorage in decision-making

What is the relation between decision-making in networks and representative democracy? In the review article concluding this special issue Van Bortel and Mullins explore issues of democratic anchorage in relation to urban regeneration, community involvement and the integration of minority groups.

- We need to further develop network governance methodologies

In each of the articles in this special issue the research method is primarily the case study using in-depth interviews and desk research. In two articles the researchers attended and participated in key events during decision-making (see Mullins and Jones and Van Bortel).

The focus on process and the use of case studies as a predominant research approach in network governance analysis ideally requires longitudinal data collection to capture the richness of decision-making dynamics. This is time-consuming for both the researchers and the individuals and organizations that are the focus of the research. Access to individual key decision-makers may be difficult to achieve and well-developed interview skills are necessary to draw out aspects that interviewees may not wish to reveal but that may be critical to understanding the processes and outcomes observed. In this respect the opportunity provided to Mullins and Jones by a 3-year evaluation running in parallel with an intensive network management programme is rather unique. Budget constraints can often lead to less robust research methodologies potentially resulting in heavily biased research results. 
- We need to explore network resources

A basic assumption underpinning governance networks is that they develop around actors seeking resources to attain their goals. In the articles in this special issue some new and interesting resources come to light. In Arnhem and Amsterdam the local authorities used a form of veto power (refusing planning permissions). The use of veto power is more frequently associated with weaker actors, like tenants and residents, who have no other resources. Hertting and Mullins and Jones describe another resource, i.e., the access to information on minority group preferences that can only be obtained by other actors from interaction with community-based organizations.

- We need to explore the effects of different modes of co-ordination, i.e., markets, hierarchies and networks, on the interactions and outcomes

How does steering in the shadow of hierarchy as discussed by Buitelaar and De Kam fit in? This also connects with the dilemma presented by Hertting of the apparent need for more centralization and hierarchy within organizations to effectively participate in network governance. There is a danger within the network paradigm of looking only for network mechanisms at work in situations where markets and hierarchies may be at least as important.

- We need to explore the effects of closedness and pluriformity on the outcomes and interactions of networks

Decision-making is often fragmented into different policy arenas (housing, regeneration, social integration) and different levels (Europe, national, local, and neighbourhood). Network actors come from very different backgrounds (national and local government, private for-profit organizations, third-sector non-profit organizations, community organizations). In what way does this pluriformity influence the interactions and outcomes of networks?

Research in housing studies has already benefited enormously from the adoption and development of network governance paradigms. There is now a rich research agenda to be pursued. This will involve challenging network interpretations of housing system behaviour and distinguishing elements of behaviour that are better explained by markets or by hierarchical steering.

Open Access This article is distributed under the terms of the Creative Commons Attribution Noncommercial License which permits any noncommercial use, distribution, and reproduction in any medium, provided the original author(s) and source are credited.

\section{References}

Bogason, P., \& Zølner, B. (Eds.). (2007). Methods in democratic network governance. London: PalgraveMacMillan.

Bull, A. C., \& Jones, B. (2006). Governance and social capital in urban regeneration: A comparison between Bristol and Naples. Urban Studies, 43(4), 767-786.

Crowley, J. (2001). The political participation of ethnic minorities. International Political Science Review, $22(1), 99-121$.

Davies, J. S. (2002). The governance of urban regeneration: A critique of the governing without government thesis. Public Administration, 80(2), 301-322.

De Bruijn, J. A., \& Ten Heuvelhof, E. F. (1999). Management in netwerken. Utrecht: Uitgeverij LEMMA BV.

De Bruijn, J. A., Ten Heuvelhof, E. F., \& In't Veld, R. (2002). Process management, why project management fails in complex decision making processes. Boston, Dordrecht and London: Kluwer Academic Publishers. 
Entwistle, T., Bristow, G., Hines, F., Donaldson, S., \& Martin, S. (2007). The dysfunctions of markets, hierarchies and networks in meta-governance of partnership. Urban Studies, 44(1), 63-79.

Fennema, M. (2004). The concept and measurement of ethnic community. Journal of Ethnic and Migration Studies, 30, 429-447.

Healey, P. (1997). Collaborative planning: Shaping places in fragmented societies. Basingstoke: Macmillan.

Hudson, J., \& Lowe, S. (2004). Understanding the policy process. Bristol: The Policy Press.

Jones, P., \& Evans, J. (2006). Urban regeneration, governance and the state: Exploring notions of distance and proximity. Urban Studies, 43(9), 1491-1509.

Kickert, W. J. M., Klijn, E. H., \& Koppenjan, J. F. M. (1997a). Managing networks in the public sector: Findings and reflections (Chapter 10). In W. J. M. Kickert, E. H. Klijn, \& J. F. M. Koppenjan (Eds.), Managing complex networks; strategies for the public sector. London: Sage Publications.

Kickert, W. J. M., Klijn, E. H., \& Koppenjan, J. F. M. (Eds.). (1997b). Managing complex networks; strategies for the public sector. London: Sage Publications.

Kickert, W. J. M., \& Koppenjan, J. F. M. (1997). Public management and network management: An overview. In W. J. M. Kickert, E. H. Klijn, \& J. F. M. Koppenjan (Eds.), Managing complex networks; strategies for the public secto. London: Sage Publications.

Klijn, E. H., \& Skelcher, C. (2007). Democracy and governance networks, compatible or not? Public Administration, 85(3), 587-608.

Klijn, E. H., \& Teisman, G. R. (1997). Strategies and games, in networks. In W. J. M. Kickert, E. H. Klijn, \& J. F. M. Koppenjan (Eds.), Managing complex networks. Strategies for the public sector. London: Sage.

Koffijberg, J. (2005). Getijden van beleid: Omslagpunt in volkshuisvesting. Over de rol van hiërarchie en netwerken bij grote veranderingen. [Tides of policy: turning points in public housing. On the role of hierarchy and networks in the management of change]. Delft: Delft University Press.

Koppenjan, J. F. M., \& Klijn, E. H. (2004). Managing uncertainties in networks. London: Routledge.

Markussen, M., \& Torfing, J. (Eds.). (2007). Democratic network governance in Europe. London: PalgraveMacMillan.

Mullins, D., \& Rhodes, M. L. (2007). Editorial special issue on network theory and social housing. Housing Theory and Society, 24(1), 1-13.

Scharpf, F. W. (1997). Games real actors play: Actor-centered institutionalism in policy research. Boulder: Westview Press.

Sørensen, E., \& Torfing, J. (Eds.). (2007). Theories of democratic network governance. London: PalgraveMacMillan.

Swyngedouw, E. (2005). Governance innovation and the citizen: The janus face of governance-beyond-thestate. Urban Studies, 42(11), 1991-2006.

Teisman, G. R. (1998). Complexe besluitvorming, een pluricentrisch perspectief op besluitvorming over ruimtelijke investeringen [Complex decision-making, a pluri-centric perspective on decision-making in spatial investments]. The Hague: Elsevier.

Van Bortel, G. A., Van Bueren, E., Van Eeten, M., Elsinga, M., \& Kerpershoek, E. (2007). Rhetoric of success in Dutch urban renewal: the role of personal chemistry and trust in networks. Paper presented at the ENHR 2007 conference in Rotterdam. [accessible at www.enhr2007rotterdam.nl].

Williamson, O. E. (1996). The mechanics of governance. New York: Oxford University. 